\title{
Aspects of parr-smolt transformation in anadromous and resident forms of brown trout (Salmo trutta) in comparison with Atlantic salmon (Salmo salar)
}

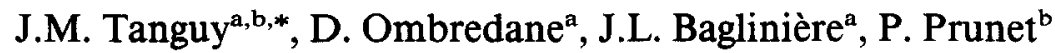 \\ aINRA, Laboratoire d'Ecologie Hydrobiologique, 65 rue de Saint-Brieuc, 35042 Rennes Cedex, \\ France \\ 'INRA, Laboratoire de Physiologie de Poissons, Campus de Beaulieu, 35042 Rennes Cedex, France
}

\begin{abstract}
This study established the existence of a parr-smolt transformation in the anadromous form of brown trout but no such change in the resident form when reared under ambient photoperiod and temperature. Smolting occurred in March-April in the larger trout of the anadromous form and in April-May in salmon. Silvering, a peak of gill $\mathrm{Na}^{+}, \mathrm{K}^{+}$-ATPase activity and a simultaneous decrease in plasma prolactin were observed in both salmon and the anadromous form of trout. Bimodality in length frequency and a surge in growth hormone were observed only in Atlantic salmon. No physiological or morphological changes were observed in smaller $(<13 \mathrm{~cm})$ trout of the anadromous form or in the resident form. Hypo-osmoregulatory ability was greatest at the time of peak gill $\mathrm{Na}^{+}, \mathrm{K}^{+}$-ATPase activity and increased in spring in all trout, irrespective of smolt status. It is concluded that smolting is not as well developed in brown trout as in Atlantic salmon, and is not necessary for seawater adaptation of brown trout. It is also dependent on both stock origin and fish size.
\end{abstract}

\section{Introduction}

The life history of brown trout can vary considerably between populations (L'Abée-Lund et al., 1989). Three forms have been described (Frost and Brown, 1967). A river form spends its entire life cycle in rivers, whereas lake or sea forms migrate to a lake or the sea after modifications in morphology and behaviour (Baglinière, 1991). These three types have been studied extensively (see review

"Corresponding author. Tel. (+33) 99-28-54-49; Fax (+33) 99-28-54-40. 
in Elliott, 1989, and Baglinière and Maisse, 1991), but the smolt status of the various types in a single river system, especially the river and the sea types, has not been clarified (Maisse and Baglinière, 1991).

Gordon (1959), Oduleye (1976), Boeuf and Harache (1982), Quillet et al. (1986) and Madsen (1990) have reported on various aspects of seawater adaptation (osmotic regulation and gill $\mathrm{Na}^{+}, \mathrm{K}^{+}$-ATPase activity) in Salmo trutta. Soivio et al. (1989) and Muona and Soivio (1992) conducted integrated studies of smolting in the species. Migratory behaviour of silvered fish and capacity for seawater adaptation suggest that Salmo trutta undergoes smoltification.

Bimodality in length frequency distribution in late summer-autumn is well known in cultured and wild populations of Atlantic salmon (Thorpe, 1977; Baglinière et al., 1993); the upper modal group complete smolting the following spring and the lower modal group a year later. Such bimodality has not been reported for Salmo trutta.

The objective of our study was to investigate length frequency bimodality and other smolt criteria such as seawater tolerance, condition factor, gill $\mathrm{Na}^{+}, \mathrm{K}^{+}$ATPase activity, silvering, ionic $\left(\mathrm{Na}^{+}\right.$and $\left.\mathrm{Cl}^{-}\right)$content, prolactin and growth hormone levels in anadromous and resident Salmo trutta in comparison with Atlantic salmon.

\section{Material and methods}

Brown trout from a wild anadromous stock of the River Orne (Normandy), resident brown trout from La Gouarnais hatchery (Brittany) and Atlantic salmon from a Scottish domestic stock were studied. Fish were reared from January 1990 to June 1991 at Coquainvilliers hatchery (Normandy). After hatching, the fry were kept indoors for 3 months at constant temperature $\left(11.5^{\circ} \mathrm{C}\right)$, then transferred outdoors to $2-\mathrm{m}^{2}$ tanks, under natural water temperature $\left(0-15^{\circ} \mathrm{C}\right)$ and photoperiod $\left(49^{\circ} \mathrm{N}\right)$. They were fed with dry pelleted feed (Aqualim, France). Representative samples were measured and weighed at the beginning (October 1990), middle (January 1991) and end of the experiment (June 1991). Fork length, weight and mortality are presented in Table 1. Mortalities occurred among the smaller fish of each group in association with low winter temperature $\left(>3^{\circ} \mathrm{C}\right)$. Mortalities occurred in May-June and affected mainly the salmon and trout smolts. These smolts lost scales and were more sensitive to various pathogenic agents.

In October 1990, the salmon were measured and divided into two size groups (lower modal group 40-80 cm; upper modal group 80-120 cm) and both modes were pelvic fin clipped. The trout were measured and divided into lower, middle and upper size groups (Table 1). Trout from upper and lower size groups were pelvic fin clipped. A single fin-clip does not affect survival and growth of brown trout (O'Grady, 1984; Johnsen and Ugedal, 1988). Fish from the middle size group were not marked or sampled for physiological changes. Sampling occurred 
Table 1

Length, weight and mortality of Atlantic salmon and two forms of brown trout. Fish were marked as to size groups in October. Mean length (s.e.) of 500 fish and mean weight (s.e.) of 100 fish

\begin{tabular}{|c|c|c|c|c|c|c|c|}
\hline & \multirow{2}{*}{$\frac{\text { Length range }(\mathrm{mm})}{\text { Oct. } 90}$} & \multicolumn{2}{|c|}{ Mean length (mm) } & \multicolumn{2}{|c|}{ Mean weight (g) } & \multicolumn{2}{|c|}{ Mortality (\%) } \\
\hline & & Oct. 90 & Jun. 91 & Oct. 90 & Jun. 91 & Winter & Spring \\
\hline \multicolumn{8}{|l|}{ Atlantic salmon } \\
\hline Lower group & $40-80$ & $69(6)$ & $95(10)$ & $3.5(1.0)$ & $9.5 \quad(2.8)$ & 22 & 12 \\
\hline Upper group & $80-120$ & $100(6)$ & $147(9)^{*}$ & $11.2(2.0)$ & $29.7(4.2)^{*}$ & $<1$ & 100 \\
\hline \multicolumn{8}{|c|}{ Anadromous trout } \\
\hline Lower group & $50-90$ & $78(8)$ & $156(19)$ & $5.9(1.8)$ & $47.3(16.9)$ & 45 & 10 \\
\hline Middle group & $90-100$ & $94(3)$ & $178(11)$ & $10.4(1.2)$ & $68.5(13.8)$ & 6 & 25 \\
\hline Upper group & $100-135$ & $110(9)$ & $193(13)$ & $17.2(4.3)$ & $89.0(21.4)$ & $<1$ & 53 \\
\hline \multicolumn{8}{|l|}{ Resident trout } \\
\hline Lower group & $60-105$ & $95(7)$ & $147(18)$ & $10.1(2.4)$ & $36.9(13.1)$ & 13 & $<1$ \\
\hline Middle group & $105-110$ & $107(1)$ & $170(10)$ & $13.9(1.3)$ & $56.0(11.6)$ & 7 & $<1$ \\
\hline Upper group & $110-150$ & $118(8)$ & $188(16)$ & $20.1(4.7)$ & $78.0(22.2)$ & $<1$ & $<1$ \\
\hline
\end{tabular}

*15 May.

Table 2

Morphological criteria used to distinguish brown trout parr, pre-smolts and smolts

\begin{tabular}{|c|c|c|c|c|}
\hline & Coat & Sides & Red spots & Fins \\
\hline Parr & $\begin{array}{l}\text { dark coat } \\
\text { brown back } \\
\text { yellowish abdomen }\end{array}$ & $\begin{array}{l}\text { regular } \\
\text { parr marks } \\
\text { on sides }\end{array}$ & numerous & $\begin{array}{l}\text { anal: black and white margin } \\
\text { caudal: red margin } \\
\text { adipose: red }\end{array}$ \\
\hline Pre-smolt & $\begin{array}{l}\text { silvery and } \\
\text { sparkling coat }\end{array}$ & $\begin{array}{l}\text { pronounced } \\
\text { lateral line }\end{array}$ & few & $\begin{array}{l}\text { nearly colorless fins } \\
\text { red adipose fin }\end{array}$ \\
\hline Smolt & $\begin{array}{l}\text { silvery and } \\
\text { sparkling coat }\end{array}$ & $\begin{array}{l}\text { pronounced } \\
\text { lateral line }\end{array}$ & none & $\begin{array}{l}\text { colourless fins } \\
\text { red adipose fin }\end{array}$ \\
\hline
\end{tabular}

once a month from November 1990 to February 1991 and twice a month from March to May 1991.

Fish were fasted 3 days before sampling. After anaesthetization (phenoxyethanol, $\left.0.5 \mathrm{ml} \cdot 1^{-1}\right)$, Atlantic salmon were classified as parr or smolt based on silvering (Johnston and Eales, 1970). Both brown trout forms were classified as parr, pre-smolt or smolt, based on external morphology. Criteria for distinguishing morphological types in brown trout are defined in Table 2. Salmon parr were sampled from November to May in the lower mode and from November to February in the upper mode. Salmon smolts were sampled from the upper mode from March to May. Trout parr were sampled from both the upper and lower size groups of each stock from November to May, except in the upper size group of the anadromous stock in which parr sampling ended in February. Sampling of pre-smolts from the upper size group of the anadromous stock was conductued from Febru- 
ary to May. Smolts in the upper size group of the anadromous form were sampled from March to May. Sample size was 10-15 individuals per phenotype. Very few smolts $(n=12)$ were observed in the resident form of brown trout. They were all sampled. No blood sampling was performed in the lower size group of salmon.

Blood was collected from the caudal blood vessel with a heparinized syringe. After centrifugation, plasma was frozen in liquid nitrogen and kept at $-20^{\circ} \mathrm{C}$ until analysis. Gills were removed, rinsed in $0.25 \mathrm{M}$ sucrose, and frozen in liquid nitrogen. They were kept at $-70^{\circ} \mathrm{C}$ until analysis. Fork length $(1 \mathrm{~mm})$ and weight $(0.1 \mathrm{~g})$ were measured.

Condition factor (CF) was calculated by: $\mathrm{CF}=10^{5} \cdot\left(\mathrm{W} / \mathrm{L}^{3}\right) \cdot \mathrm{Na}^{+}, \mathrm{K}^{+}$-ATPase activity was determined according to the method of Stagg and Shuttleworth (1982). Plasma prolactin (PRL) and plasma growth hormone (GH) levels were determined by RIA, according to the methods of Prunet et al. (1985) and Le Bail et al. (1991) respectively.

Eight seawater challenge tests were performed in 30 ppt seawater (Instant Ocean synthetic salt) in static $2-\mathrm{m}^{2}$ tanks. Water temperatures during tests were at rearing levels and varied from $2-3^{\circ} \mathrm{C}$ in November-December to $10-12^{\circ} \mathrm{C}$ in May. After $24 \mathrm{~h}$, blood was collected from surviving fish. Plasma chloride concentration was measured using a chloridometer (ISA Biologie CL500). Plasma sodium concentration was measured using an atomic absorption spectrophotometer (Varian AA1275).

The Shapiro-Wilk normality and Bartlett homoscedasticity tests were used, followed by parametric methods when distributions were normal (Student's $t$ test or Aspin-Welsh's test, ANOVA) and non-parametric methods when distributions differed from normality or variances were heterogenous (Mann-Whitney's U test or Kruskal-Wallis's $H$ test followed by Noether test ).

\section{Results}

Size distribution was always normal (unimodal) in resident trout (Fig. 1). Distribution was significantly $(P<0.001)$ skewed toward the greater lengths in anadromous trout, though two distinct modes did not appear. In salmon, the size distribution was bimodal $(P<0.005)$.

The condition factor in the lower size groups showed no significant seasonal variation, ranging from 1.0 to 1.2 in trout and from 0.9 to 1.0 in salmon. In the upper size group of both trout forms, condition factor decreased by $11-13 \%$ between January and March $(P<0.01 ;$ Fig. 2$)$. It remained low until May, with a subsequent increase in June, reaching values similar to those in February. In salmon, condition factor decreased by $15 \%$ between January and May $(P<0.01)$.

In the upper size group of the anadromous trout, gill $\mathrm{Na}^{+}, \mathrm{K}^{+}$-ATPase activity increased three-fold between November and March $(P<0.01 ;$ Fig. 3$)$. Activity remained high until mid-April, when a significant decrease $(P<0.01)$ was observed. In the lower size group of the anadromous trout, no significant increase of enzymatic activity occurred during spring. There was no significant difference 


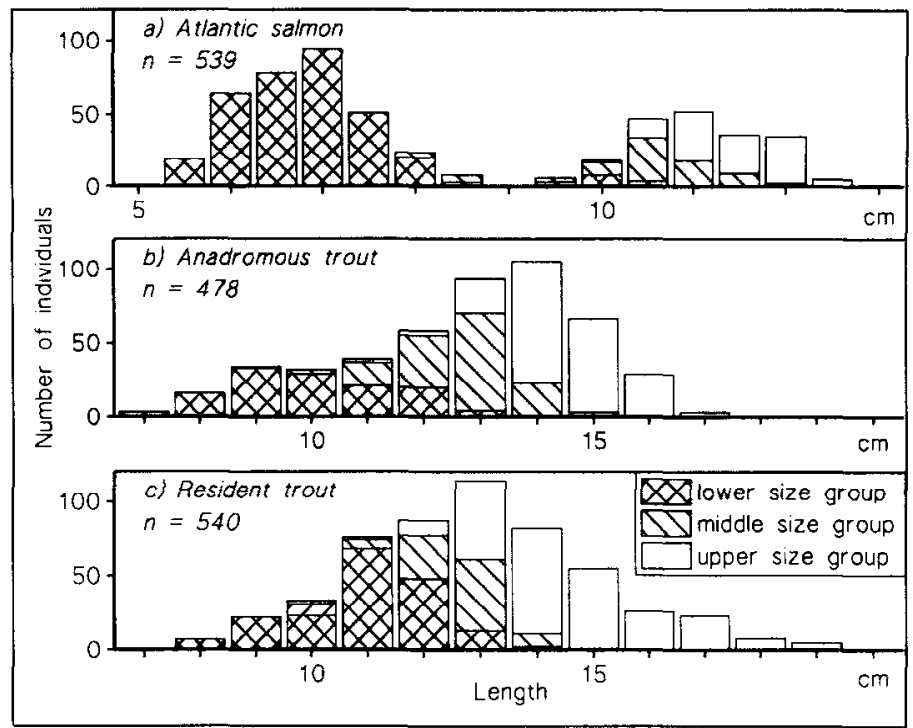

Fig. 1. Length frequency histogram of fork length in Atlantic salmon and two forms of brown trout, measured in January 1991 on representative samples. Size groups identified by fin clipping in October 1990.

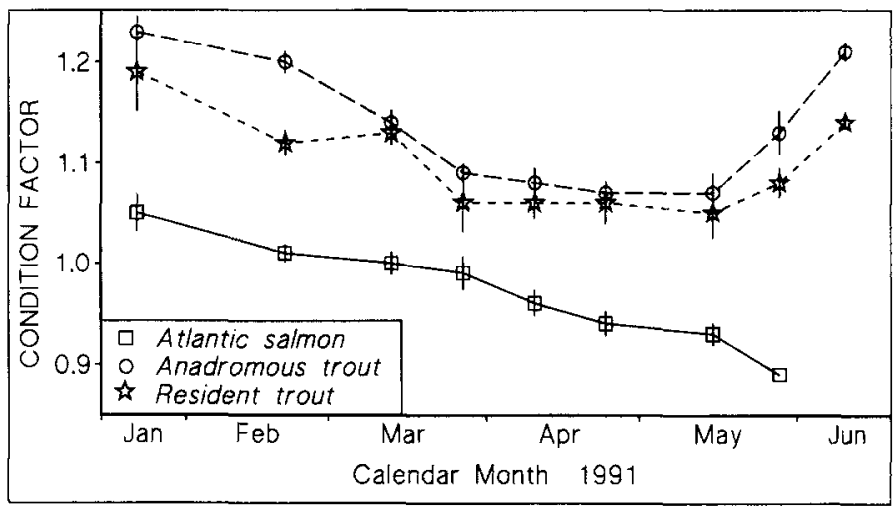

Fig. 2. Condition factor in upper size groups of Atlantic salmon and two forms of brown trout during parr-smolt transformation. Each point represents the mean \pm s.e.m. of 25 to 30 fish.

in $\mathrm{Na}^{+}, \mathrm{K}^{+}$-ATPase activity between upper and lower size groups before February, when silvering occurred in the larger fish. Thereafter, $\mathrm{Na}^{+}, \mathrm{K}^{+}$-ATPase activity was significantly higher $(P<0.01)$ in the upper size group (smolts) than in the lower size group (parr). Activities in pre-smolts were intermediate.

The resident trout showed no significant variation in gill $\mathrm{Na}^{+}, \mathrm{K}^{+}$-ATPase activity, but in March, some individuals $(n=5)$ were silvered and had high gill enzymatic activity $\left(>3.5 \mu \mathrm{m} \mathrm{Pi} \cdot \mathrm{mg} \mathrm{Prot}^{-1} \cdot \mathrm{h}^{-1}\right)$.

Gill $\mathrm{Na}^{+}, \mathrm{K}^{+}$-ATPase activity increased seven-fold $(P<0.01)$ in upper mode 


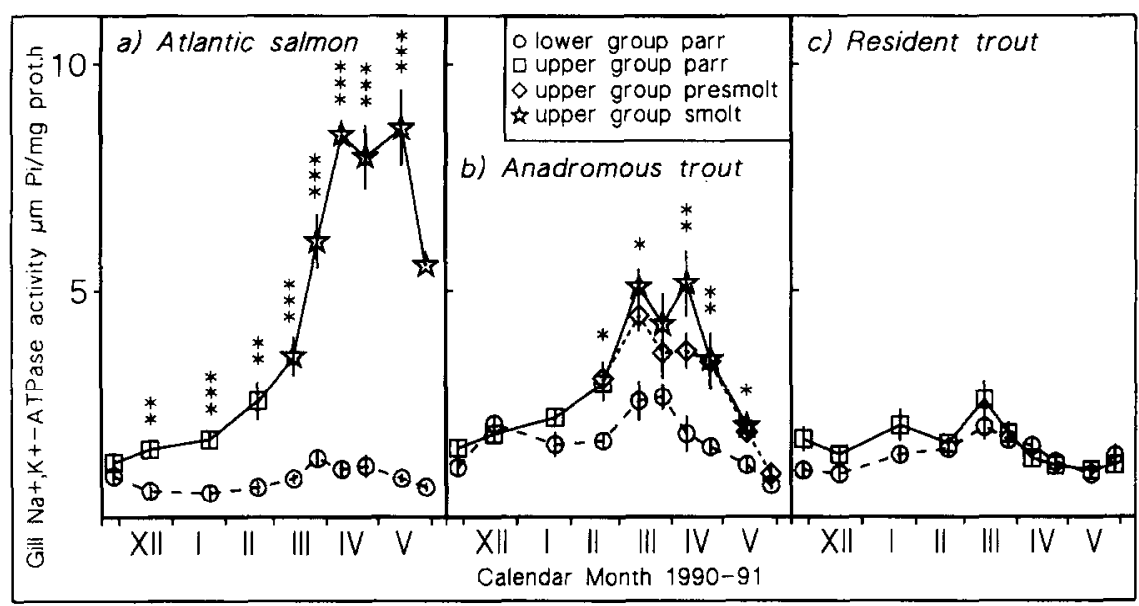

Fig. 3. Gill $\mathrm{Na}^{+}, \mathrm{K}^{+}$-ATPase activity of Atlantic salmon and two forms of brown trout during parrsmolt transformation. Each point represents the mean \pm s.e.m. of 7 to 10 fish. Stars indicate significant differences between upper and lower size groups (Student's $t$ test). ${ }^{*} P<0.05{ }^{* *} P<0.01$. $* P<0.001$. See text for distinction between parr, pre-smolt and smolt.

salmon between January and April, where it reached a plateau and then declined in late May. There was no significant variation in gill $\mathrm{Na}^{+}, \mathrm{K}^{+}$-ATPase activity in lower mode salmon.

Both forms of trout showed no significant change in plasma electrolyte concentration. Although no variation was detected in electrolyte concentration of trout in fresh water, sodium increased significantly in upper mode salmon during February-March $(P<0.05)$ and remained high during April-May (Fig. 4). In seawater, survival of upper size group fish was $100 \%$ (10/10 in salmon and the anadromous trout) or very high (9/10 to $10 / 10$ in the resident trout) and did not vary from January onwards. Survival in lower size groups of both trout forms varied between $3 / 10$ and $9 / 10$, and increased together with the mean size of fish. No trout larger than $145 \mathrm{~mm}$ died and no trout smaller than $110 \mathrm{~mm}$ survived the tests. There were no surviving lower mode salmon after $24 \mathrm{~h}$ tests.

In all fish challenged with seawater, plasma chloride and sodium levels decreased between December and March-April, then increased until late May (Fig. 4). Decreases in plasma chloride were significant $(P<0.01)$ in upper size groups only; subsequent increases were not significant. Variations in sodium were significant $(P<0.05)$ only in the upper size groups of both trout forms.

In the upper size group of anadromous trout, mean prolactin concentrations were about $5 \mathrm{ng} \cdot \mathrm{ml}^{-1}$ from November to February (Fig. 5 ). A temporary, significant $(P<0.01)$ increase in prolactin level was observed in smolts in March, reaching a peak of $10 \mathrm{ng} \cdot \mathrm{ml}^{-1}$ before decreasing significantly $(P<0.01)$ to February levels. In the lower size group of the anadromous trout, prolactin increased gradually from December to April $(P<0.01)$, then decreased slowly, reaching December values in late May $(P<0.01)$. In April-May, the difference in plasma 


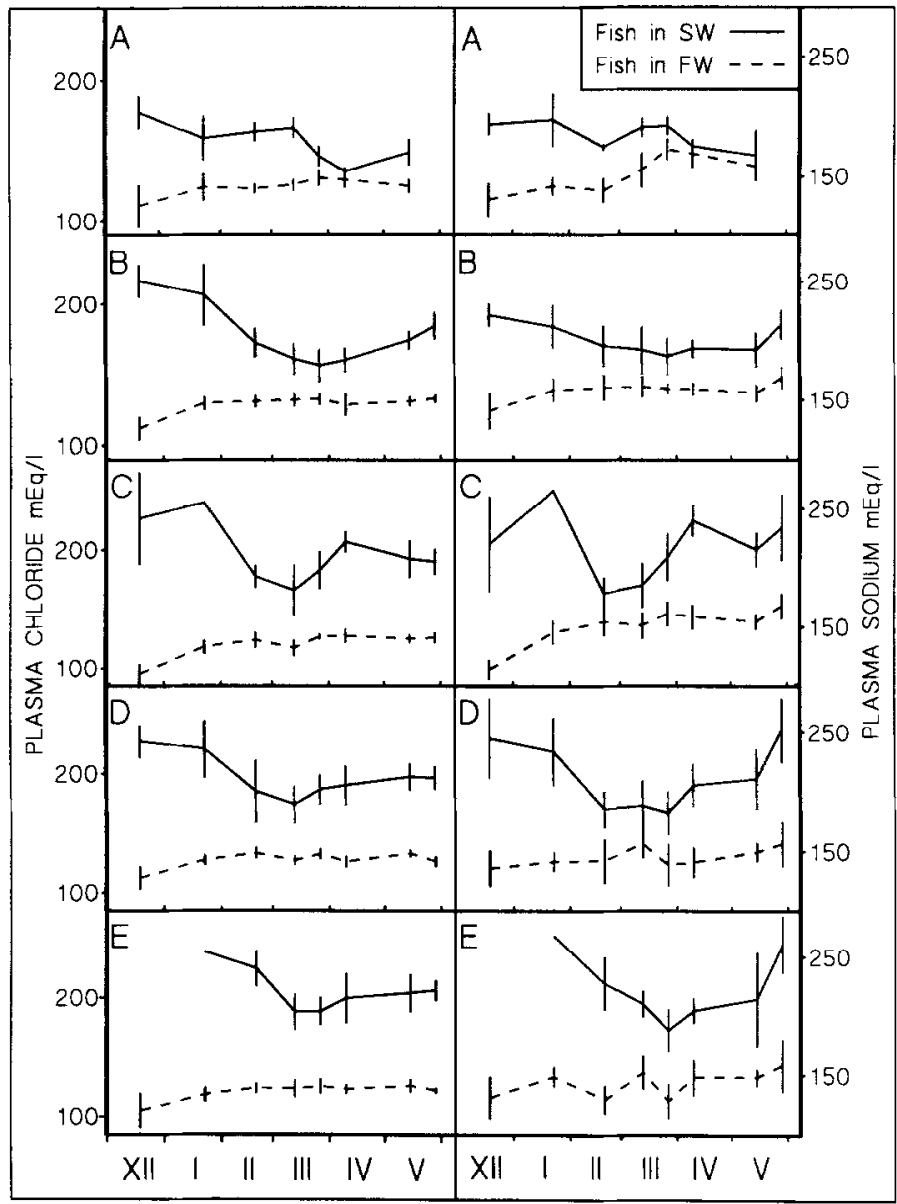

Calendar Month 1990-91

Fig. 4. Variations in plasma chloride and sodium of fish transferred to $30 \mathrm{ppt}$ seawater and sampled after $24 \mathrm{~h}$. A: upper modal group of Atlantic salmon. B: upper size group, anadromous brown trout. $\mathrm{C}$ : lower size group, anadromous brown trout. $\mathrm{D}$ : upper size group, resident brown trout. E: lower size group, resident brown trout. SW: fish in seawater. FW: fish in fresh water. Each point represents the mean \pm s.e.m. of 1 to 10 fish. All lower modal group Atlantic salmon died prior to $24 \mathrm{~h}$ in $30 \mathrm{ppt}$ seawater.

PRL concentration between the upper size group (smolts) and the lower size group (parr) was significant $(P<0.01)$. In the resident form, the plasma PRL level increased between December and February-March $(P<0.01)$, but no decrease was observed later in the season. In upper modal salmon, plasma PRL concentration rose ten-fold from November through April, reaching a peak of 10 $\mathrm{ng} \cdot \mathrm{ml}^{-1}$. Thereafter, PRL concentration dropped $(P<0.01)$ and stayed at a low level until May.

There was no significant seasonal variation in plasma growth hormone levels in either the anadromous or resident form of trout (Fig. 6), nor a significant 


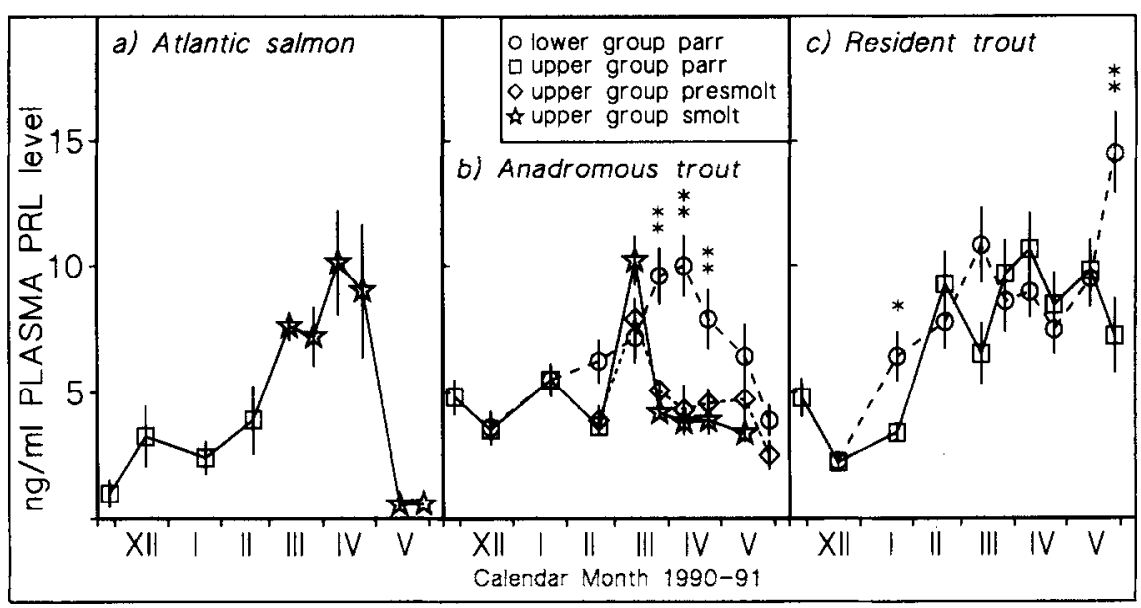

Fig. 5. Plasma prolactin levels of Atlantic salmon and two forms of brown trout during parr-smolt transformation. Each point represents the mean \pm s.e.m. of 7 to 10 fish. Stars indicate significant differences between upper and lower size groups (Student's $t$ test). $* P<0.01$. See text for distinction between parr, pre-smolt and smolt.

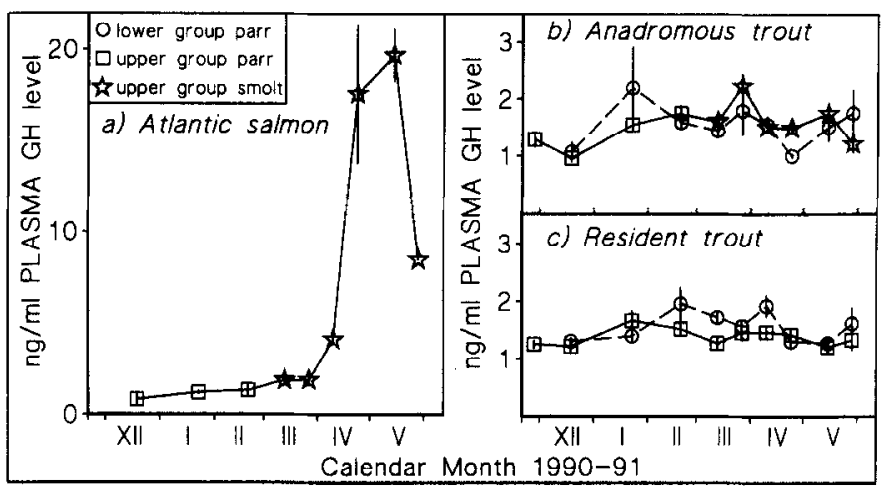

Fig. 6. Plasma growth hormone levels of Atlantic salmon and two forms of brown trout during parrsmolt transformation. Each point represents the mean \pm s.e.m. of 7 to 10 fish. See text for distinction between parr, pre-smolt and smolt.

difference between upper and lower size groups. In contrast, plasma GH levels increased dramatically $(P<0.01)$ in upper modal salmon during April-May.

\section{Discussion}

An increase in gill $\mathrm{Na}^{+}, \mathrm{K}^{+}$-ATPase activity in the spring was as characteristic of the parr-smolt transformation of brown trout as of other salmonids (Zaugg and McLain, 1970; Zaugg and Wagner, 1973; McCartney, 1976). The three-fold 
increase in enzyme activity in smolts and pre-smolts of the anadromous form, with no change in parr of the resident form, is in agreement with Boeuf and Harache (1982), Soivio et al. (1989) and with results obtained from trout under wild conditions (Tanguy, 1993). Thus, our results suggest that anadromous brown trout are preadapted to marine life before their entrance into seawater. Gill $\mathrm{Na}^{+}, \mathrm{K}^{+}$-ATPase activity was lower in those pre-smolts which kept some phenotypical characters of parr (red spots and visible parr marks), than in totally silvered smolts. Accordingly, a small increase in enzymatic activity, measured in a few resident trout, was always accompanied by increased silvering. Thus, the level of gill $\mathrm{Na}^{+}, \mathrm{K}^{+}$-ATPase can be directly related to fish phenotype and both can be used in brown trout to evaluate the degree of parr-smolt transformation.

Morphological changes associated with smolting were less clear between the anadromous and resident forms of trout. Changes in condition factor were not specific to smolting trout, as this parameter decreased in spring in both forms. Therefore, condition factor was not a useful criterion for smolting in brown trout. In contrast, a decrease in condition factor has been demonstrated in smoltifying Atlantic salmon juveniles (Saunders and Henderson, 1978) and in young lakemigrating brown trout (Champigneulle et al., 1988). Fessler and Wagner (1969) found large differences in condition factor between smolting and non-smolting steelhead trout (Oncorhychus mykiss).

Silvering appeared in February in anadromous trout, but only 12 of 1700 resident trout achieved this coloration during the experiment. Hence, silvering is the only reliable morphological factor to discriminate parr and smolt of brown trout prior to migration. Before silvering appears, there is no morphological method to estimate the proportions of migratory and sedentary fish in natural or domestic trout populations. Our results suggest that parr-smolt transformation in brown trout may have a genetic component (Jonsson, 1982), as silvering and characteristic physiological changes were observed only in the migratory strain and not in the resident one.

Changes during parr-smolt transformation of the Atlantic salmon in this study were similar to previous studies (see reviews by Hoar, 1988; Borgatti et al., 1992). The results emphazized that parr-smolt transformation in anadromous trout was neither as clear nor as complete as in Atlantic salmon. In both species, gill $\mathrm{Na}^{+}, \mathrm{K}^{+}$. ATPase activity increased in early spring. However, while there was no further increase from March in trout, the surge lasted longer in salmon. Furthermore, the peak in gill $\mathrm{Na}^{+}, \mathrm{K}^{+}$-ATPase activity of Atlantic salmon was twice that in brown trout, confirming the findings of Muona and Soivio (1992).

In winter, plasma PRL levels increased in both forms of trout. A significant drop in plasma PRL occurred in March only in the anadromous form. The plasma levels of PRL in the anadromous and the resident trout were similar to that previously described in Atlantic salmon smolts and parr respectively (Prunet and Boeuf, 1989).

Patterns of plasma GH changes were totally different between salmon and anadromous brown trout. Plasma GH reached its maximum in May in salmon smolts, but remained low in both trout forms. Furthermore, GH levels were pos- 
itively correlated with gill $\mathrm{Na}^{+}, \mathrm{K}^{+}$-ATPase activity in Atlantic salmon $\left(r^{2}=0.78\right.$; $n=37 ; P<0.01$ ), as suggested by Prunet et al. (1989). This hormone is known to increase seawater adaptation in Atlantic salmon (Komourdjian et al., 1976) independently of its action on growth (Bolton et al., 1987) and probably acts directly at the level of the gills (Prunet et al., 1994). In brown trout, exogenous GH also improves seawater adaptation (Smith, 1956) and increases gill $\mathrm{Na}^{+}, \mathrm{K}^{+}$. ATPase activity (Madsen, 1990; Almendras et al., 1993). In our study, gill $\mathrm{Na}^{+}, \mathrm{K}^{+}$-ATPase activity increased in the anadromous form of brown trout without any observable variation in plasma $\mathrm{GH}$ level, indicating that the peak in gill $\mathrm{Na}^{+}, \mathrm{K}^{+}$-ATPase activity is not entirely under $\mathrm{GH}$ control.

Bimodality in length frequency distribution was not observed in anadromous trout and the size distribution of the underyearling population did not allow for an early discrimination between migrating and resident juveniles. It is also interesting to note that such a lack of bimodality coincided with the absence of a GH surge in brown trout during parr-smolt transformation.

The high mortalities that occurred both in salmon and anadromous trout smolts have been explained by the fact that these smolts lost scales and were thus sensitive to pathogenic agents. Boeuf (1993) reported similar spring mortality in Atlantic salmon smolts maintained in fresh water after time of migration and suggested that this was due to the absence of desmoltification in southern populations of Atlantic salmon. Further information is thus necessary to know if this point is a characteristic of our warmer conditions or if scale loss is the only explanation.

Parr-smolt transformation is associated with an increase in seawater adaptability. However, differences in parr-smolt transformation observed among groups in this study were not reflected by differences in seawater survival. On the one hand, larger anadromous trout reacted as salmon smolts, as no mortality was observed after the seawater challenge tests, corroborating the results of Boeuf and Harache (1982) and Soivio et al. (1989). Plasma electrolytes after the seawater challenge were low at the time of peak gill $\mathrm{Na}^{+}, \mathrm{K}^{+}$-ATPase activity (Boeuf and Harache, 1982; Hogstrand and Haux, 1985). On the other hand, osmoregulatory ability and seawater survival improved in spring in the resident trout and in small anadromous trout, even though no physiological changes could be observed in those fish. The fact that $30 \mathrm{ppt}$ seawater was used could explain why no differences were found in salinity tolerance between anadromous and resident forms of trout. A greater seawater challenge could have detected such differences between groups and seasonal variations within groups. Duston and Saunders (1990) emphazized the difference in salinity tolerance of Atlantic salmon between $24 \mathrm{~h} /$ $29 \mathrm{ppt}$ and $96 \mathrm{~h} / 37 \mathrm{ppt}$ tests; the former test is not a sufficient challenge. However, several studies demonstrate good survival in resident trout transferred to seawater in spring, with mortality occurring mainly in smaller fish (Boeuf and Harache, 1982; Belaud et al., 1984; Soivio et al., 1989). Furthermore, it has been possible to transfer fish weighing more than $40 \mathrm{~g}$ to seawater in autumn (Quillet et al., 1986) and to obtain satisfactory growth and survival (Krieg et al., 1992). These results confirm that seawater performance in brown trout depends on individual size as well as on smolt status. In fact, salinity tolerance improves with 
size in all salmonids (McCormick and Saunders, 1987). Development of salinity tolerance, independent of parr-smolt transformation, exists naturally in non-anadromous salmonids, such as Salvelinus fontinalis (McCormick et al., 1985), and can be stimulated by seawater transfer in landlocked forms, such as kokanee salmon, Oncorhynchus nerka (Foote et al., 1992), and resident brown trout (Quillet et al., 1986; this study).

In conclusion, changes occurring in parr-smolt transformation in brown trout were not as clear as in Atlantic salmon. Moreover, this transformation did not seem necessary for seawater adaptation in Salmo trutta. However, it could have provided a short-term advantage by allowing more rapid seawater adaptation. It would be interesting to know whether parr-smolt transformation also has a longterm advantage, for example by preventing sexual maturation in the same year (Thorpe, 1987) and increasing duration of seawater life (Maisse et al., 1991) or growth capacity in seawater. If so, parr-smolt transformation would play a fundamental role in the life history strategy of brown trout.

\section{Acknowledgments}

We thank D. Surville and P. Couturier, from Coquainvilliers hatchery, who produced the fish, and the FDAAPP (union of angling associations) of Calvados who authorized this in their hatchery. We express our gratitude to S. Azam and F. Marchand for their help during sampling and to B. Auperin, M.J. Ricordel and Y. Le Graet for their advice during analysis. We thank organisators of the fourth smolt workshop, particulary Dr. R.L. Saunders, for their invitation to the workshop and their help in the final writing of the paper. This work was supported by a "Région Basse-Normandie" grant to J.M. Tanguy and by financial support of SRETIE (French department of environment), "Conseil Supérieur de la Pêche", "Région Basse-Normandie" and "Région Bretagne" (BRITTA program).

\section{References}

Almendras, J.M.E., Prunet, P. and Boeuf, G., 1993. Responses of a non-migratory stock of brown trout, Salmo trutta, to ovine growth hormone treatment and seawater exposure. Aquaculture, 114: 169-179.

Baglinière, J.L., 1991. La truite commune (Salmo trutta L.), son origine son aire de répartition, ses interêts économique et scientifique. In: J.L. Baglinière and G. Maisse (Editors), La Truite: Biologie et Écologie. INRA Editions, Paris, pp. 11-22.

Baglinière, J.L. and Maisse, G. (Editors), 1991. La Truite: Biologie et Écologie. INRA Editions, Paris, $303 \mathrm{pp}$.

Baglinière, J.L., Maisse, G. and Nihouarn, A., 1993. Comparison of two methods of estimating Atlantic salmon (Salmo salar) wild smolt production. In: R.J. Gibson and R.E. Cutting (Editors), Production of Juvenile Atlantic Salmon, Salmo salar, in Natural Waters. Can. J. Fish. Aquat. Sci., 118.

Belaud, A., Yany, G., Kugler, J. and Labat, R., 1984. Comparaison de l'adaptation à la salinité de Salmo trutta entre variétés migratrice et sédentaire. Ichtyophysiologica Acta, 8: 26-40. 
Boeuf, G., 1993. Salmonid smolting: a pre-adaptation to oceanic environment. In: J.C. Rankin and F.B. Jensen (Editors), Fish Ecophysiology. Chapman and Hall, London, pp. 106-135.

Boeuf, G. and Harache, Y., 1982. Criteria for adaptation of salmonids to high salinity seawater in France. Aquaculture, 28: 163-176.

Bolton, J.P., Collie, N.L., Kawaauchi, H. and Hirano, T., 1987. Osmoregulatory actions of growth hormone in rainbow trout Salmo gairdneri. J. Endocrinol., 112: 63-68.

Borgatti, A.R., Pagliarani, A. and Ventrella, V., 1992. Gill $\left(\mathrm{Na}^{+}, \mathrm{K}^{+}\right)$-ATPase involvement and regulation during salmonid adaptation to salt water. Comp. Biochem. Physiol., 102A: 637-643.

Champigneulle, A., Melhaoui, M., Maisse, G., Baglinière, J.L., Gillet, C. and Gerdeaux, D., 1988. Premières observations sur la truite dans le Redon, un petit affluent frayère du lac Leman. Bull. Fr. Pêche Piscic., 310: 59-76.

Duston, J. and Saunders, R.L., 1990. The entrainment role of photoperiod on hypoosmoregulatory and growth-related aspects of smolting in Atlantic salmon (Salmo salar). Can. J. Zool, 68: 707715.

Elliott, J.M., 1989. Wild brown trout: the scientific basis for their conservation and management. Freshwater Biol., 21: 137.

Fessler, J.L. and Wagner, H.H., 1969. Some morphological and biochemical changes in steelhead trout during the parr-smolt transformation. J. Fish. Res. Board Can., 26: 2823-2841.

Foote, C.J., Wood, C.C., Clarke, W.C. and Blackburn, J., 1992. Circannual cycle of seawater adaptability in Oncorhynchus nerka: genetic differences between sympatric sockeye salmon and kokanee. Can. J. Fish. Aquat. Sci., 49: 99-109.

Frost, W.E. and Brown, M.E., 1967. The Trout. Collins, London, $236 \mathrm{pp.}$

Gordon, M.S., 1959. Osmotic and ionic regulation in Scottish brown trout and sea trout (Salmo trutta L.). J. Exp. Biol., 36: 253-260.

Hoar, W.S., 1988. The physiology of smolting salmonids. In: W.S. Hoar and D.J. Randall (Editors), Fish Physiology, Vol. XI, part B. Academic Press, San Diego, CA, pp. 275-343.

Hogstrand, C. and Haux, C., 1985. Evaluation of the seawater challenge test on the seatrout, Salmo trutta. Comp. Biochem. Physiol., 82A: 261-266.

Johnsen, B.O. and Ugedal, O., 1988. Effects of different kinds of fin-clipping on over-winter survival and growth of fingerling brown trout, Salmo trutta, stocked in small streams in Norway. Aquacult. Fish. Manage., 19: 305-311.

Johnston, C.E. and Eales, J.G., 1970. Influence of body size on silvering of Atlantic salmon (Salmo salar) at parr-smolt transformation. J. Fish. Res. Board Can., 27: 983-997.

Jonsson, B., 1982. Diadromous and resident trout Salmo trutta: is their difference due to genetics? Oikos, 38: 297-300.

Komourdjian, M.P., Saunders, R.L. and Fenwick, J.C., 1976. The effect of porcine somatotropin on growth and survival in sea water of Atlantic salmon (Salmo salar). Can. J. Zool., 54: 531-535.

Krieg, F., Quillet, E. and Chevassus, B., 1992. Brown trout, Salmo trutta L.: a new species for intensive marine aquaculture. Aquacult. Fish. Manage., 23: 557-566.

L'Abée-Lund, J.H., Jonsson, B., Jensen, A.J., Saettem, L.M., Heggeberget, T.G., Johnsen, B.O. and Naesje, T.F., 1989. Latitudinal variation in life history characteristics of sea-run migrant brown trout Salmo trutta. J. Anim. Ecol., 58: 525-542.

Le Bail, P.Y., Sumpter, J.P., Carragher, J.F., Mourot, B., Niu, P.D. and Weil, C., 1991. Development and validation of highly sensitive radioimmunoassay for chinnook salmon (Oncorhynchus tshaw$y t s c h a$ ) growth hormone. Gen. Comp. Endocrinol., 83: 75-85.

Madsen, S.S., 1990. The role of cortisol and growth hormone in seawater adaptation and development of hypoosmoregulatory mechanism in sea trout parr, Salmo trutta. Gen. Comp. Endocrinol., 79: $1-11$.

Maisse, G. and Baglinière, J.L., 1991. Connaître les bases biologiques de la gestion, une idée toujours d'actualité pour la truite (Salmo trutta). In: J.L. Baglinière and G. Maisse (Editors), La Truite: Biologie et Écologie. INRA Editions, Paris, pp. 297-302.

Maisse, G., Mourot, B., Breton, B., Fostier, A., Marcuzzi, O., Le Bail, P.Y., Baglinière, J.L. and Richard, A., 1991. Sexual maturity in sea trout, Salmo trutta L., running up the River Calonne (Normandy, France) at the "finnock" stage. J. Fish Biol., 39: 705-715. 
McCartney, T.H., 1976. Sodium potassium dependent adenosine triphosphatase activity in gills and kidncys of Atlantic salmon (Salmo salar). Comp. Biochem. Physiol., 53A: 351-353.

McCormick, S.D. and Saunders, R.L., 1987. Preparatory physiological adaptations for marine life of salmonids: osmoregulation, growth and metabolism. Am. Fish Soc. Symp., 1: 211-229.

McCormick, S.D., Naiman, R.J. and Montgomery, E.T., 1985. Physological smolt characteristics of anadromous and non-anadromous brook trout (Salvelinus fontinalis) and Atlantic salmon (Salmo salar). Can. J. Fish. Aquat. Sci., 42: 529-538.

Muona, M. and Soivio, A., 1992. Changes in plasma lysozyme and blood leucocyte levels of hatcheryreared Atlantic salmon (Salmo salar L.) and sea trout (Salmo trutta L.) during parr-smolt transformation. Aquaculture, 106: 75-87.

Oduleye, S.O., 1976. The effects of hypophysectomy, prolactin therapy and environmental calcium on freshwater survival and salinity tolerance in the brown trout, Salmo trutta. J. Fish Biol., 9: 463470.

O'Grady, M.F., 1984. The effect of fin-clipping, floy-tagging and fin-damage on the survival and growth of brown trout (Salmo trutta) stocked in Irish lakes. Fish. Manage., 15: 49-58.

Prunet, P. and Boeuf, G., 1989. Plasma prolactin levels during smolting in Atlantic salmon, Salmo salar. Aquaculture, 82: 297-305.

Prunet, P., Boeuf, G. and Houdebine, L.M., 1985. Plasma prolactin levels in rainbow trout during the adaptation to different salinities. J. Exp. Zool., 235: 187-196.

Prunet, P., Boeuf, G., Bolton, J.P. and Young, G., 1989. Smoltification and seawater adaptation in Atlantic salmon (Salmo salar): plasma prolactin, growth hormone and thyroid hormones. Gen. Comp. Endocrinol., 74: 355-364.

Prunet, P., Pisam, M. and Rambourg, A., 1994. Effects of growth hormone on gill chloride cells and ion exchanges in Atlantic salmon (Salmo salar) juveniles. Am. J. Physiol. (in press).

Quillet, E., Krieg, F., Happe, A. and Chevassus, B., 1986. Etude des possibilités de transfert automnal en mer des juveniles de truite fario (Salmo trutta). Bull. Fr. Pêche Piscic., 303: 125-133.

Saunders, R.L. and Henderson, E.B., 1978. Changes in gill ATPase activity and smolt status of Atlantic salmon (Salmo salar). J. Fish. Res. Board Can., 35: 1542-1546.

Smith, D.C.W., 1956. The role of endocrine organs in the salinity tolerance of trout. Mem. Soc. Endocrinol., 5: 83-101.

Soivio, A., Muona, M. and Virtanen, E., 1989. Smolting of two populations of Salmo trutta. Aquaculture, 82: 147-153.

Stagg, R.M. and Shuttleworth, T.J., 1982. $\mathrm{Na}^{+}, \mathrm{K}^{+}$-ATPase ouabain binding and ouabain sensitive oxygen consumption in gills from Platichthys flesus adapted to seawater and freshwater. J. Comp. Physiol., 147: 93-99.

Tanguy, J.M., 1993. La smoltification de la truite de mer (Salmo trutta L.): caractérisation éco-physiologique des juvéniles en milieu contrôlé et en milieu naturel. Ph.D. thesis, Ecole Nationale Supérieure Agronomique, Rennes, France. 107 pp.

Thorpe, J.E., 1977. Bimodal distribution of length of juvenile Atlantic salmon (Salmo salar L.) under artificial rcaring conditions. J. Fish Biol., 11: 175-184.

Thorpe, J.E., 1987. Smolting versus residency: developmental conflict in salmonids. Am. Fish Soc. Symp., 1: 244-252.

Zaugg, W.S. and McLain, L.R., 1970. Adenosine triphosphatase activity in gills of salmonids: seasonal variations and salt water influence in coho salmon, Oncorhynchus kisutch. Comp. Biochem. Physiol., 35: 587-596.

Zaugg, W.S. and Wagner, H.H., 1973. Gill ATP-ase activity related to parr-smolt transformation and migration in steelhead trout (Salmo gairdneri): influence of photoperiod and temperature. Comp. Biochem. Physiol., 45B; 955-965. 